\title{
Construction of Practice Education Mode of Anti- terrorism Specialty in Police Colleges
}

\author{
Qiang Guo* \\ dept. Criminal Investigation \\ Criminal Investigation Police University of China \\ Shenyang, China \\ royinchina@163.com
}

\author{
Xuemei An \\ dept. Criminal Investigation \\ Criminal Investigation Police University of China \\ Shenyang, China \\ royinchina@163.com
}

\author{
Hui Zhou \\ dept. Criminal Investigation \\ Criminal Investigation Police University of China \\ Shenyang, China \\ royinchina@163.com
}

\begin{abstract}
The practice education mode is a crucial platform for practical training between the teaching of anti-terrorism specialty in college and policing vocational practice in a counterterrorism unit. This paper presents the need to further deepen the reform of practical education and training of anti-terrorism specialty in undergraduate police college, and analyze a series of problems existing in the construction of standardized practice mode. It also expounds on the way to improve the incomplete practice system, unclear practice standards and unsound basebuilding practice, which can enhance the level of regularization, specialization and professionalization of the probationary public security staff, by the focus of construction of corresponding capabilities of the specialty. From the aspects of the organizational system, rules and regulations, the content of construction, and the security system, construction standards of practice education mode of anti-terrorism specialty are established.
\end{abstract}

Keywords - construction of standardized practice mode; public security colleges; anti-terrorism specialty; criminal investigation

\section{INTRODUCTION}

Nowadays, police education is again at a crossroads which is resurfacing as a 'hotspot' in contemporary policing, with a number of jurisdictions across the world wanting to address the topic head-on [1]. In order to adapt to the current high-speed economic growth, the complex and severe situation of social security, and the public security units urgently need a group of senior specialized personnel who have a solid grasp of the basic theory of public security, strong practical ability and certain innovative ability. For this goal, public security colleges should follow the training thought of co-operation and cocultivation between the school and the bureau. While vigorously promoting and improving the teaching reform in colleges, the construction of practice mode should fully rely on the educational resources such as training teachers and public security organs to build practical teaching bases outside schools with public security organs. Police colleges or public security colleges should conscientiously strengthen the

13th Five-Year Plan of Education Science in Liaoning Province (No. JG16DB491, JG17DB551) construction of training bases and strengthen the training of post vocational ability [2]. It has become an important way to improve the quality of teaching in all ways.

\section{ThE NECESSITY OF CONSTRUCTING PRACTICAL TEACHING BASE FOR ANTI-TERRORISM SPECIALTY}

In recent years, with the rapid development of vocational education, public security colleges have trained a large number of high-quality applied talents for public security organs and made important contributions to improving the quality of basiclevel police and law enforcement. However, some problems exist in the characteristics of vocational education in some public security colleges. The effectiveness of teaching and training is not high, and teaching cannot be synchronized with public security practice. In order to ensure the quality of personnel training and actively explore the reform of teaching mode of integration of teaching, learning, training and fighting, public security colleges can unite with practical departments to promote order-based training, which jointly formulate personnel training plans and evaluation standards, build practical training bases, cooperate in teaching, and infiltrate the training of post vocational ability into professional teaching system.

\section{A. The practical requirement for talent-cultivation mode}

Police academies adhere to the principle of facing the group of basic-level police and the practices, pursuing the actual effect and cultivating practical talents which can fit in with the demand of anti-terrorism units. Consequently, the position of practical teaching in the whole teaching link has been greatly improved. But there are still some problems in public security colleges, such as the lack of prominent characteristics of vocational education, the ineffectiveness of teaching and training, and the lack of synchronization between teaching and public security practice. It is necessary to strengthen professional experience and speed up the integration of theory and practice, so as to set clear goals and directions for 
improving the structure of professional knowledge and ability, as well as group communication skills, strong organization coordinated ability with a certain degree of teamwork spirit, which are closely related to the investigation profession [3].

The ability to identify terrorist and organization coordination, the capability of emergency response and antiterrorism treatment, are the essential factors to adapt to the development and change of the anti-terrorism situation. It is an effective way to solve the shortcomings of education in public security colleges to build practical teaching bases out of campus with public security organs.

\section{B. Practice Training is the Direction of the Reform of Public Security Vocational Education}

Police colleges should actively study the law of the transformation from diploma education of public security specialty to professional teaching, and adhere to the direction of reform firmly. According to the actual needs of public security and the position of personnel training, the colleges should in accordance with the essential characteristics and connotation requirements of vocational education through the practice base, and strengthen the practice teaching link that increase the proportion of practical teaching courses, and optimize the environment of personnel training as well as reform. The reform of the current practice training mode, the enhancement of the teaching of public security specialty and the form of distinct characteristics of public security schoolrunning, can definitely improve the level of the police vocational education.

\section{An Important Component of the Integrated Teaching Mode of Teaching, Learning, Training, and Combating}

Training refers to practical teaching, which mainly includes in-school and out-of-school practical training, public security probation and professional practice, degree thesis, etc. The professional practice of anti-terrorism speciality is an important part of practical teaching. By participating in professional practical work in public security organs, students' theoretical knowledge can be consolidated and deepened. The police awareness can be also cultivated, and their ability to solve practical problems can be improved as well.

\section{Problems Existing In The Professional Practice OF ANTI-TERRORISM SPECIALTY}

The unclear standard of practice, the unelaborated plan of practice, and the unstandardized arrangement of practice is the existing problem in professional practice. In order to ensure the quality of personnel training, and explore the reform of teaching mode of integration of teaching, learning, training and warfare, public security colleges and universities can unite with practical departments to promote order-based training, and formulate personnel training plans and evaluation standards jointly, as well as build practical training bases, cooperate in teaching, and infiltrate the training of post vocational ability into professional teaching system.

\section{A. Unclear Practice Standards, Unelaborate Plan and not Standardized Arrangement of Practice}

At present, practice standard is not so clear as the practice training time is not fixed. For the anti-terrorism specialty, police colleges usually adopt the talent cultivation plans which are professional foundation courses learning with one year and anti-terrorism knowledge study with three years. Thus, practice time is not enough for police vocational education when limited time is given. Besides that, the practice plan is unelaborated as the impact of safety and security task for largescale security activities, which make comprehensive internship become a special internship for the security of large-scale activities. Finally, there is neither quantitative nor qualitative requirement, and the content of practice is relatively not detailed.

\section{B. The Construction of Practice Base is not Standardized}

The working environment, accommodation conditions and other hardware construction are relatively standardized, but there is a lack of a sound management and training system for interns. In the process of practice, some practice units lack the necessary professional guidance for students, some practice units do not arrange specific instructors for interns at all, which policemen on duty will take students to do, what kind of work they encounter and what kind of work they do, and use interns as assistant policemen, which makes students' practice lack of systematisms, orderliness and integrity [4]. The students who mainly study in the anti-terrorism specialty cannot even participate in a complete process of handling counter terrorism cases, lacking specific guidance for interns. Besides that, the status of students is not in the position of counter terrorism police, which means sensitive information are not allowed open to them.

\section{Non-Standard Practical Education Management}

Teachers, who cannot guide the practice of students and find out the problems in practice in time, are only responsible for the management and do not participate in every business link of practical training. The lack of effective communication with the practice units, coupled with no effective reflection of the relevant problems, as well as the management of the entire practice process are a mere formality.

\section{Construction of Practice Education Mode}

The construction of professional practice mode must be closely focused on the professional competence of students majoring in anti-terrorism. The terrorist identifying ability, emergency response capability, cooperative engagement capacity and anti-terrorism treatment capacity are the key factors for the construction mode, the details as follows.

\section{A. Construction Principles}

\section{1) Fine rules and standards}

According to the requirements of the Ministry of Public Security, we strive to achieve the specialization of law enforcement team, standardization of law enforcement behavior, law enforcement management system and informationization of law enforcement process with three or 
five years. Fine rules and standards are the lifelines of the construction of law enforcement standardization. As the cradle of training police personnel, police colleges and universities must be precise in all aspects of teaching, experiment, practical training and practice in order to train qualified police personnel.

\section{2) Favorable to the realization of training objectives}

It is conducive to the realization of training objectives and the cultivation of core vocational abilities. The goal of talent cultivation in colleges and universities in the 21st century requires us to have a new concept of talent quality that integrates knowledge, ability and quality education. Police academies are no exception. The cultivation of core professional competence of high-quality applied police personnel is the key. The practice is an essential link to transform knowledge into ability. The students should have the ability of case investigation, on-site disposal, communication with the masses and related police skills, depending on practical teaching links such as training, practice and so on.

\section{3) Easy to operate}

Whether the formulation of the internship outline, the internship program, the internship system, or the establishment of the specific internship management and evaluation system, we should not only have an empty talk but should be operable and practical.

\section{B. Construction of Practice Education Mode of Anti- terrorism Speciality}

1) Designing a clear and scientific practice syllabus

It is necessary to formulate a scientific and rigorous practice outline with clear objectives and put forward specific requirements for practice. The internship is also a process of applying and testing the professional knowledge and related knowledge learned in class in specific public security work, enhancing students' perceptual awareness and cultivating students' practical ability. It should be noted that the practice police instructor has rich experience in handling cases and strong practical operation ability, but they generally lack systematic professional and theoretical knowledge, and their teaching level is relatively low. In order to improve the professional theoretical level and teaching ability of the police and ensure the quality of practical teaching off-campus, the school can send full-time college teachers to develop training projects for improving the teaching skills of the police instructors, which aims at the personality and characteristics of the instructors to help improve their language expression ability, design teaching reasonably and arrange teaching inclass.

\section{2) Establishment of an operable internship program.}

Combining with the professional knowledge of various professional courses in public security science, we can establish practical programs with operability. First of all, practice content should be detailed and specific, which involves the acquaintance of information prediction system, antiterrorism treatment, awareness of counterterrorism, daily files editing and finishing. Practice positions should be in line with the corresponding skills requirements of professional courses, and cannot be arranged randomly. This requires a lot of preparatory work, understand the basic situation of each student, and make the post arrangements correspond to professional expertise. Then, the assessment requirements for students must be measurable.

3) Strengthening the management of the practice process

The duration of professional practice is long. In order to ensure that the internship process is carried out in accordance with the syllabus and established teaching plan, the trainee's internship activities are under effective supervision of the college, which improves the organization and management mode of teaching and adopts the double instructor system to manage and teach students. Firstly, building direct practice exchange platforms in all aspects involves face-to-face, Internet, written and other channels. Secondly, the rules and regulations for obtaining daily record supervised by practice units and guide teacher should be implemented. Thirdly, ensuring the carry-out and obedience to the process discipline should be also in high priority. The construction of practice education base is based on the anti-terrorism department of public security organs, which has determined the practice teaching mode of transmitting experience, aiding with ideology, and leading the work style [5]. Guided by the practice instructor of public safety organs, the students' practice work is specifically arranged. Then the teaching activities and the offcampus practical teaching plan are also organized and implemented. The college dispatches full-time teachers to each practice teaching point as assistant tutors who take the responsibility of supervision and inspection on the teaching progress of the trainees in stages to provide professional theoretical support for the trainees and put forward suggestions and ideas for solving problems from a professional standpoint. It also helps to organize the content of off-campus practical teaching with the help of police instructors.

4) Establishment of a scientific quality monitoring and evaluation system for practice

Establishing a scientific practice quality monitoring system and evaluation system plays a very important role in improving the efficiency of practice and mobilizing the enthusiasm of practice bases and students. Firstly, according to the characters of anti-terrorism specialty, a reasonable integral evaluation system is established for practice. It is composed of the scores of basic practices workload, extra completion and innovation completion of practice workload. Academic achievements of students cannot be simply evaluated in the form of practice report. Secondly, making an achievement exhibition of student practice to strengthen publicity in various ways including social tools, panels, posters and electronic displays media, can enhance motivation and the sense of achievement among students.

\section{5) Setting up a training base mode based on the demand of} job position

It is necessary to establish a demand-oriented training model to highlight the comprehensive training of core investigative skills. The content of off-campus practice of investigation and anti-terrorism specialty should closely focus on the specialty characteristics and strengthen the comprehensive training of core professional skills. In accordance with the procedure of investigation cases and the requirement of investigation post ability, the content of on- 
campus practice training of investigation and anti-terrorism specialty has been divided into several modules such as cases acceptance module, crime scene investigation for terrorism module, investigation measures and means module, and evidence collection for terrorism module, to carry out skill training [6]. In the practice off-campus, much attention should be paid to the integration and comprehensive application of the above skills, and the training of establishing evidence awareness, procedural awareness and strategic awareness in the implementation of each investigation link.

Considering that the students do not have the right to enforce the law, the training of core investigative terrorism skills should be set as a compulsory item in off-campus practical teaching. Students are required to participate in an anti-terrorism training, visit an anti-terrorism command center, familiarize themselves with a counter-terrorism disposal process, and learn a counter-terrorism case.

6) Emphasis on the Development of the Professional Quality of Investigation and Anti-terrorism

Because the terrorism investigation procedure and the implementation of investigative measures are strictly regulated by anti-terrorism law, a set of the standardized mode of law enforcement and handling cases are highly modeled to accomplish the anti-terrorism task. However, we should recognize the complexity and variability of terrorism cases. Even though the same type of cases they seem alike, each terrorism case is actually unique as the complexity and variability.

\section{CONCLUSION}

Practice education of anti-terrorism is an important part of practical teaching in public security college. It is also an important link for students to consolidate and deepen their theoretical knowledge, cultivate police awareness, which can improve students' ability to solve practical problems by using their knowledge, and promote the efficient connection between teaching and police practice. The key of cultivation of applied police personnel is integrated vocational capacity- building. The ability of counter terrorism and policing skills possessed by students majoring in anti-terrorism must be enhanced through practical links such as training and practice. Therefore, standardizing the practice mode of anti-terrorism specialty and transforming knowledge into vocational ability effectively are the necessary ways for management to the developments of policing education.

In this paper, we demonstrate the importance of establishing practical education mode, and introduce how to do it well from multiple dimensions. Restricted by objective conditions, the hardware conditions of some practical teaching points fail to meet the requirements of practical teaching. There are still some problems in daily management, such as poor communication between the colleges and the bureau, weak supervision, limitation of case sensitivity. Consequently, strengthening the research on the theory and practice of the construction of off-campus practical teaching base for investigation specialty should be a dynamic subject for sustainable and in-depth exploration in public security colleges and universities.

\section{REFERENCES}

[1] B.T Isabelle, "Research in police education: current trends," Police Practice and Research, vol.20, No.3, pp. 220-224, 2019.

[2] Williams, J. Norman, and M. Rowe. "The police education qualification framework: a professional agenda or building professionals?,” Police Practice and Research, vol.20, No.3, pp. 259-272, 2019.

[3] Y.C Mo, and H.B. Cheng. "Practice and Research of Off-campus Practical Teaching Bases in Police Colleges,” Journal of Guangxi Police College, vol.31, No.1, pp.116-121,2018. (In Chinese)

[4] X. Liu, "Research on Practice Management Model of Practice Teaching Base for Public Security College Students," Journal of Yunnan Police College, vol.113, No.5, pp.7-10, 2015. (In Chinese)

[5] H. I. Gundhus, "Experience or knowledge? Perspectives on new knowledge regimes and control of police professionalism,” Journal of Policing, vol.7, No. 2, pp.178-194, 2012.

[6] H.Tong, and C. Yang, "on the Construction of Practical Teaching System in Public Security Colleges and Universities,” Journal of Beijing Police College, No. 5, pp. 116-120, 2017. (In Chinese) 